\title{
Elemental Mercury in Natural Waters: Occurrence and Determination of Particulate $\mathrm{Hg}(0)$
}

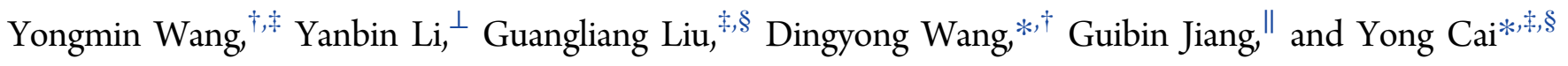 \\ ${ }^{\dagger}$ College of Resources and Environment, Southwest University, Chongqing 400715, China \\ ${ }^{\ddagger}$ Department of Chemistry and Biochemistry and ${ }^{\S}$ Southeast Environmental Research Center, Florida International University, \\ Miami, Florida 33199, United States \\ ${ }^{\perp}$ Key Laboratory of Marine Chemistry Theory and Technology, Ministry of Education, Ocean University of China, Qingdao 266100, \\ Shandong, China \\ "State Key Laboratory of Environmental Chemistry and Ecotoxicology, Research Center for Eco-Environmental Sciences, Chinese \\ Academy of Sciences, Beijing 100085, China
}

\section{Supporting Information}

ABSTRACT: Elemental mercury, $\mathrm{Hg}(0)$, is ubiquitous in water and involved in key $\mathrm{Hg}$ biogeochemical processes. It is extensively studied as a purgeable dissolved species, termed dissolved gaseous mercury (DGM). Little information is available regarding nonpurgeable particulate $\mathrm{Hg}(0)$ in water, $\mathrm{Hg}(0)$ bound to suspended particulate matter (SPM), which is presumably present due to high affinity of $\mathrm{Hg}(0)$ adsorption on solids. By employing stable isotope tracer and isotope dilution (ID) techniques, we investigated the occurrence and quantification of particulate $\mathrm{Hg}(0)$ after $\mathrm{Hg}(0)$ being spiked into natural waters, aiming to provide firsthand information on particulate $\mathrm{Hg}(0)$ in water. A considerable fraction of ${ }^{201} \mathrm{Hg}(0)$ spiked in water (about $70 \%$ after $4 \mathrm{~h}$ equilibration) was bound to SPM and nonpurgeable, suggesting the occurrence of particulate $\mathrm{Hg}(0)$ in natural waters. A scheme, involving isotope dilution, purge and trap, and inductively coupled plasma mass spectrometry detection, was proposed to quantify particulate $\mathrm{Hg}(0)$ by the difference between $\mathrm{DGM}$ and total $\mathrm{Hg}(0)$, determined immediately and at equilibration after spiking ID $\mathrm{Hg}$ isotope, respectively. The application of this newly established method revealed the presence of particulate $\mathrm{Hg}(0)$ in Florida Everglades water, as the determined DGM levels (0.14 to $0.22 \mathrm{ng}$ $\left.\mathrm{L}^{-1}\right)$ were remarkably lower than total $\mathrm{Hg}(0)\left(0.41\right.$ to $\left.0.75 \mathrm{ng} \mathrm{L}^{-1}\right)$.

\section{INTRODUCTION}

Mercury $(\mathrm{Hg})$, as a global pollutant, has received great attention due to accumulation and biomagnification of its methylation product, methylmercury $(\mathrm{MeHg})$, through aquatic food chains. Elemental mercury, $\mathrm{Hg}(0)$, is an important species in $\mathrm{Hg}$ cycling, as considerable levels of $\mathrm{Hg}(0)$ are present in all environmental media, including the atmosphere (up to $95 \%$ of $\mathrm{Hg}$ being $\mathrm{Hg}(0)),{ }^{1,2}$ soil $^{3}$ and sediment, ${ }^{4}$ and water. ${ }^{5}$ Previous studies have shown that dissolved gaseous $\mathrm{Hg}$ (DGM), being mainly composed of $\mathrm{Hg}(0)$, is a ubiquitous form of inorganic $\mathrm{Hg}$ in seawater, ${ }^{5,6}$ fresh water, ${ }^{7-9}$ and groundwater. ${ }^{10,11} \mathrm{Hg}(0)$ in water is involved in key processes of $\mathrm{Hg}$ biogeochemical cycling including air-water exchange, ${ }^{12}$ oxidation-reduction, ${ }^{8}$ and methylation-demethylation. ${ }^{13} \mathrm{Hg}(0)$ can be oxidized to $\mathrm{Hg}$ (II) by both chemical and biological processes in aquatic environments, ${ }^{6,7,14-17}$ and reduction of $\mathrm{Hg}(\mathrm{II})$ can produce $\mathrm{Hg}(0)$ in water, through photochemical processes, ${ }^{6,18-20}$ enzymatic catalysis by mercury-resistant microorganisms, ${ }^{7,21-23}$ or geochemical reactions involving humic acids and mineral-associated

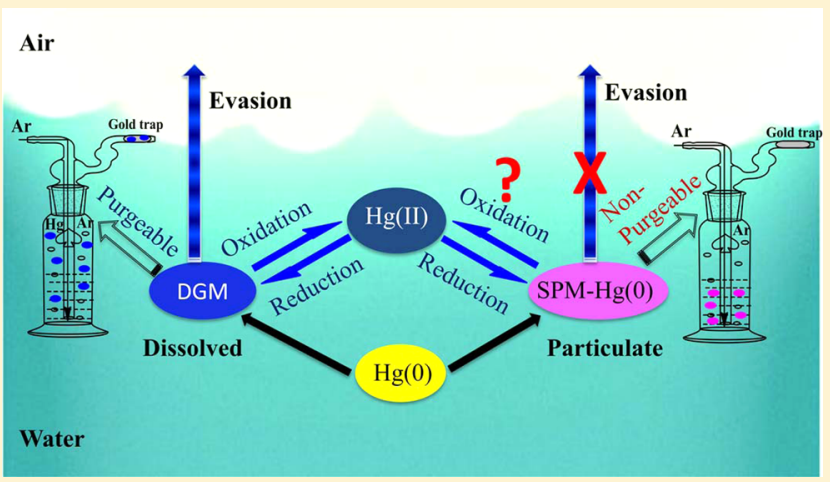

ferrous ion. ${ }^{24-27}$ It was recently observed that dissolved $\mathrm{Hg}(0)$ could be methylated by Desulfovibrio desulfuricans ND132 to form $\mathrm{MeHg},{ }^{13,14}$ which was a previously unrecognized pathway in $\mathrm{Hg}$ cycling. $\mathrm{MeHg}$ photodegradation in natural waters could also produce $\mathrm{Hg}(0)$ as an end product. ${ }^{28-30}$ It should be noted that $\mathrm{Hg}(0)$ can be present in two forms in water, liquid $\mathrm{Hg}(0)$ droplet and aqueous $\mathrm{Hg}(0)$ (denoted as $\mathrm{Hg}(0)^{\mathrm{aq}}$ for distinction in some cases), with the former being rarely observed in uncontaminated natural waters and the latter being ubiquitous and of more environmental relevance. ${ }^{8,17} \mathrm{The} \mathrm{Hg}(0)$ in this study is referred to the aqueous form, and $\operatorname{Hg}(0)$, instead of $\mathrm{Hg}(0)^{\text {aq }}$, was used throughout the paper.

Despite being ubiquitous and playing a key role in $\mathrm{Hg}$ biogeochemical cycling, $\mathrm{Hg}(0)$ in natural waters has not been

Received: April 16, 2015

Revised: June 29, 2015

Accepted: July 21, 2015

Published: July 21, 2015 
well understood with respect to its occurring forms and measurement. $\mathrm{Hg}(0)$ can be present as a dissolved species in water that has been the $\operatorname{Hg}(0)$ form being focused in the overwhelming majority of previous studies. In natural waters, $\mathrm{Hg}(0)$ could be bound to suspended particulate matter (SPM) and dissolved organic matter (DOM), with these forms of particulate $\mathrm{Hg}(0)$ and DOM-complexed $\mathrm{Hg}(0)$ being rarely studied. Although direct evidence for the presence of SPMbound particulate and DOM-complexed $\mathrm{Hg}(0)$ in water is scarce, these $\mathrm{Hg}(0)$ species are presumably present in natural waters, reasoning from previously reported sorption of $\mathrm{Hg}(0)$ on various soils, clay minerals, and other solid materials. It has been shown that charcoal, peat, humic acid (HA), and illite were among the most effective materials adsorbing $\mathrm{Hg}(0))^{3,31,32}$ and $\mathrm{Hg}(0)$ could be rapidly adsorbed on lake sediment (likely related to organic matter). ${ }^{4}$ Recently, strong interactions between reduced $\mathrm{HA}$ and $\mathrm{Hg}(0)$ through thiolated ligand-induced oxidative complexation was observed under anoxic dark conditions with an estimated binding capacity of $\sim 3.5 \mu \mathrm{mol}$ $\mathrm{Hg} / \mathrm{g} \mathrm{HA}$ and a partitioning coefficient $>10^{6} \mathrm{~mL} / \mathrm{g}$, a value similar to the binding of $\mathrm{Hg}(\mathrm{II})-\mathrm{DOM}^{33}$

The occurrence of and differentiation among dissolved, particulate, and DOM-complexed $\mathrm{Hg}(0)$ in natural waters present a challenge to a full understanding of cycling and fate of $\mathrm{Hg}(0)$ in aquatic environments. This is particularly true when considering that $\mathrm{Hg}(0)$ in water has been exclusively determined by procedures involving purge and trap aiming to directly purge $\mathrm{Hg}(0)$ out of water. ${ }^{6}$ Conventionally, water sample is purged for a certain period of time with nitrogen or argon, and the $\mathrm{Hg}(0)$ volatilized by purging was trapped on a gold-coated sand trap, followed by pyrolysis desorption and detection on atomic fluorescence spectrometry (AFS) or inductively coupled plasma mass spectrometry (ICPMS). 6,9,16,17 This method is straightforward and easy to follow, ${ }^{6,18}$ but it has critical limitations depending on how the measured data is used. This conventional method measures only the volatile or purgeable $\mathrm{Hg}(0)$ fraction of the aqueous $\operatorname{Hg}(0)$, and as such the $\operatorname{Hg}(0)$ so measured is often operationally termed DGM. If particulate $\mathrm{Hg}(0)$ is present in water, one can reasonably presume that it could not be purged efficiently from water. Indeed, lower DGM levels have been observed in surface waters with higher SPM concentrations, probably due to SPM-bound $\mathrm{Hg}(0)$ being nonpurgeable. ${ }^{34}$ The inability of the current $\mathrm{Hg}(0)$ determination method in differentiating particulate and dissolved $\mathrm{Hg}(0)$ could result in underestimation of total $\mathrm{Hg}(0)$ concentrations and incomplete information on $\mathrm{Hg}(0)$ transformation and fate in water.

The presence of particulate, nonpurgeable $\mathrm{Hg}(0)$ in water should be taken into account when studying $\mathrm{Hg}$ species transformation. As a common practice in studying the oxidation and reduction processes of $\mathrm{Hg}$ in water, a decrease in $\mathrm{Hg}(0)$ after being introduced in water is often attributed to the oxidation of $\mathrm{Hg}(0)$ to $\mathrm{Hg}(\mathrm{II}){ }^{6,18}$ This practice, however, could result in misleading conclusions due to the fact that both oxidation from $\mathrm{Hg}(0)$ to $\mathrm{Hg}(\mathrm{II})$ and reduction from $\mathrm{Hg}$ (II) to $\mathrm{Hg}(0)$ can occur simultaneously and a fraction of $\mathrm{Hg}(0)$ could rapidly become nonpurgeable upon being adsorbed onto SPM in water. In a preliminary study on $\mathrm{Hg}$ photoreduction in Everglades water performed in our laboratory, a mass balance calculation of the spiked $\mathrm{Hg}$ showed a recovery of approximately $60 \%$ using the traditional purge and trap technique, indicating that a large fraction of $\mathrm{Hg}(0)$ is nonpurgeable. Therefore, quantification of both dissolved and particulate $\mathrm{Hg}(0)$ is necessary in order to fully understand the role of $\mathrm{Hg}(0)$ in $\mathrm{Hg}$ transformation and cycling in water.

The objective of this study was to improve our understanding toward the behavior of $\mathrm{Hg}(0)$ in natural waters by evaluating the influence of SPM and $\mathrm{DOM}$ on $\mathrm{Hg}(0)$ purgeability and quantifying $\mathrm{Hg}(0)$ fractions that are both purgeable (as DGM) and nonpurgeable (as particulate $\operatorname{Hg}(0)$ being the difference between total $\mathrm{Hg}(0)$ and DGM), aiming to provide the first published study on the occurrence and quantification of particulate $\mathrm{Hg}(0)$ in water. Stable isotopic tracer ${ }^{201} \mathrm{Hg}(0)$ was spiked into natural water (with ${ }^{199} \mathrm{Hg}$ (II) being added for comparison purpose). The behavior of $\mathrm{Hg}(0)$ and $\mathrm{Hg}$ (II) was monitored through determination of $\mathrm{Hg}$ species involved in the process using isotope dilution (ID) analysis (with ${ }^{200} \mathrm{Hg}(0$ ) being ID isotope). Owing to the high accuracy and precision, both stable isotope tracer and isotope dilution techniques have been increasingly applied to $\mathrm{Hg}$ research such as determination of methylation/demethylation ${ }^{15,30,35-41}$ and reduction/oxidation rates ${ }^{35}$ and ultratrace analysis of $\mathrm{Hg}$ species in complex matrices. ${ }^{42}$ On the basis of these two techniques, a scheme based on purge and trap-ID-ICPMS was proposed for quantification of dissolved and particulate $\mathrm{Hg}(0)$ in natural waters.

\section{MATERIALS AND METHODS}

Instrumentation, Materials, and Chemicals. A PerkinElmer Elan ICPMS (Elan DRC-e) was used for detection of $\mathrm{Hg}$ isotopes. Enriched stable $\mathrm{Hg}$ isotopes of ${ }^{201} \mathrm{Hg},{ }^{200} \mathrm{Hg}$, and ${ }^{199} \mathrm{Hg}$ were obtained as $\mathrm{HgO}$ from Oak Ridge National Laboratory (Oak Ridge, Tennessee, USA) and Trace Sciences International Pilot Point (Texas, USA). Humic acids, HA1 from Acros (Sodium Salt, $50-60 \%$ as HA) and HA2 from International Humic Substance Society (Waskish HA, peat, 1R107H), were used. Detailed information for ancillary equipment (bubblers, traps, and desorption devices), other reagents (analytical grade or higher), reagent preparation, and glassware cleaning can be found in the Supporting Information.

Preparation of Isotopic $\mathrm{Hg}(0)$ Stock Solutions. The stock solutions of isotopic $\mathrm{Hg}(0)$ were prepared through reduction of $\mathrm{Hg}(\mathrm{II})$ with acidic $\mathrm{SnCl}_{2}$ solution, and detailed procedures can be found in the Supporting Information. The $\mathrm{Hg}(0)$ stock solution was kept at $4{ }^{\circ} \mathrm{C}$ in the dark and used for a period of about 30 days. For each use the concentrations of $\mathrm{Hg}(0)$ in the solutions were determined using the reverse isotope dilution by spiking natural $\mathrm{Hg}$ standard of known concentration and purity. ${ }^{43,44}$ Two $\mathrm{Hg}(0)$ stock solutions, ${ }^{201} \mathrm{Hg}(0)$ and ${ }^{200} \mathrm{Hg}(0)$, were prepared, with the former being used as tracer $\mathrm{Hg}$ isotope and the latter as the ID $\mathrm{Hg}$ isotope during ID-ICPMS quantification.

Evaluating Purgeability of $\mathrm{Hg}(0)$ from Water. All experiments in this study were conducted in triplicate and in the dark (with aluminum foil wrapping to eliminate the effect of radiation-induced reactions), unless stated otherwise. An initial experiment was conducted to evaluate the purgeability of $\mathrm{Hg}(0)$ spiked into natural water. To a quartz bottle, $100 \mathrm{~mL}$ of water collected from a small lake located at Florida International University (FIU) or DI water (as control) was added. The lake water was determined to have a $\mathrm{pH}$ of 8.0 and contain a SPM concentration of $5.2 \mathrm{mg} \mathrm{L}^{-1}$ and DOC of $5.7 \mathrm{mg} \mathrm{L}^{-1}$. The lake water is primarily from rainwater runoff and contains little plant debris or algae, and the SPM is expected to be mainly composed of inorganic minerals (though which could be naturally coated with organic matter). Internal headspace was minimized to prevent loss of $\mathrm{Hg}(0)$ by volatilization. These water samples were 
spiked with ${ }^{201} \mathrm{Hg}(0)$ stock solution to achieve a concentration of approximately $4.0 \mathrm{ng} \mathrm{L}^{-1}$ of $\mathrm{Hg}(0)$, and the $\mathrm{Hg}$ spike levels used in all the experiments were about a few $\mathrm{ng} \mathrm{L}^{-1}$ for the study to be environmentally relevant. The samples were slowly transferred to a $150 \mathrm{~mL}$ bubbler after being left at room temperature for 0,1 , and $4 \mathrm{~h}$. Once being transferred into the bubbler, the sample was purged immediately with $\operatorname{Ar}\left(350 \pm 35 \mathrm{~mL} \mathrm{~min}^{-1}\right)$ to collect $\mathrm{Hg}(0)$ onto a gold trap. Release of the collected $\mathrm{Hg}(0)$ was performed by heating the trap at $500^{\circ} \mathrm{C}$ with an Ar flow of $200 \pm$ $20 \mathrm{~mL} \mathrm{~min}{ }^{-1}$, followed by detection of $\mathrm{Hg}$ isotopes using ICPMS. The nonpurgeable $\mathrm{Hg}$ in solution was determined following $\mathrm{BrCl}$ oxidation for $24 \mathrm{~h} .{ }^{33,45}$ After oxidation, $\mathrm{Hg}$ in the solution was reduced by $\mathrm{SnCl}_{2}$ and determined using ICPMS.

Examining Effects of SPM and DOM on Purgeability of $\mathrm{Hg}(0)$ from Natural Waters. As the initial experiment showed that not all $\mathrm{Hg}(0)$ after spiking was purgeable with time, further experiments were conducted to examine if the nonpurgeable $\mathrm{Hg}(0)$ is associated with SPM or DOM. To assess the effect of DOM on purging efficiency of $\mathrm{Hg}(0)$, DI water $(100 \mathrm{~mL})$ with varying HA concentrations $\left(0,0.1,0.3,1.3,5.3 \mathrm{mg} \mathrm{L}^{-1}\right.$ for HA1 and $0,0.2,0.5,1.8,7.3,14.5 \mathrm{mg} \mathrm{L}^{-1}$ for HA2) was spiked at approximately $4.2 \mathrm{ng} \mathrm{L}{ }^{-1}$ of ${ }^{201} \mathrm{Hg}(0)$. After $4 \mathrm{~h}$ of equilibrium, the solutions were transferred to bubblers and analyzed for $\mathrm{Hg}(0)$ following the similar purging, desorption, and detection procedures aforementioned. The influence of SPM on purging efficiency of $\mathrm{Hg}(0)$ was determined by comparing the results of water samples with or without filtration using a $0.45 \mu \mathrm{m}$ polyvinylidene fluoride (PVDF) filter. The water samples were spiked with $4.2 \mathrm{ng} \mathrm{L}^{-1}$ of ${ }^{201} \mathrm{Hg}(0)$ and left in the dark for $4 \mathrm{~h}$ before purging and analysis of $\mathrm{Hg}(0)$.

A separate experiment was carried out to further evaluate the time-dependent purging efficiency of $\mathrm{Hg}(0)$ and the kinetics of the equilibration between the spiked $\mathrm{Hg}(0)$ isotope and ambient $\mathrm{Hg}$. Lake water $(100 \mathrm{~mL})$ in quartz bottles was spiked with ${ }^{201} \mathrm{Hg}(0)$ at a final concentration of approximately $6.6 \mathrm{ng} \mathrm{L}^{-1}$, and a series of bottles with such a sample was prepared. Three bottles (as triplicate) were taken, purged, and determined for purgeable $\mathrm{Hg}(0)$ at $0,0.5,1,4,8,24,48$, and $72 \mathrm{~h}$, respectively. At each time interval, the water samples after purging were subjected to oxidation with $\mathrm{BrCl}$, followed by reduction with $\mathrm{SnCl}_{2}$ and purging with $\mathrm{Ar}$ for analysis of nonpurgeable $\mathrm{Hg}(0)$ (so termed for discussion purpose). Similar experiments using DI water instead of lake water were carried out as controls. For mass balance calculation, the sum of purgeable and nonpurgeable $\mathrm{Hg}(0)$ was compared with the amount of $\mathrm{Hg}(0)$ spiked.

Fractionation of Dissolved and Particulate $\mathrm{Hg}$ in Natural Water after $\mathrm{Hg}(0)$ Being Spiked. Our experiments suggest that significant loss of purgeable $\mathrm{Hg}(0)$ after being spiked in natural water was attributed to adsorption on SPM present in the sample. To further examine the presence of SPM-bound particulate $\mathrm{Hg}(0)$, i.e. the $\mathrm{Hg}$ adsorbed on SPM after $\mathrm{Hg}(0)$ being spiked is still in the oxidation state $\mathrm{Hg}(0)$ rather than being present in the mercuric form $\mathrm{Hg}$ (II), a series of speciation analysis experiments were conducted. Two $\mathrm{Hg}$ isotopes, ${ }^{201} \mathrm{Hg}(0)$ and ${ }^{199} \mathrm{Hg}(\mathrm{II})$, were simultaneously spiked into the lake water at final concentrations of approximately 7.83 and $13.56 \mathrm{ng} \mathrm{L} \mathrm{L}^{-1}$ of $\mathrm{Hg}$, respectively. Simultaneous addition of ${ }^{199} \mathrm{Hg}$ (II) can provide useful information on species conversation and distribution during the course of experiments. The sample was equilibrated at $22 \pm 1.0{ }^{\circ} \mathrm{C}$ in the dark for $4 \mathrm{~h}$. Control experiments using DI water suggest that loss of $\mathrm{Hg}$ and speciation transformation during the procedures are negligible, as $87-92$ and $91-96 \%$ of ${ }^{201} \mathrm{Hg}(0)$ and ${ }^{199} \mathrm{Hg}$ (II) can be recovered. The $\mathrm{Hg}$ species was operationally divided into three fractions, including directly purgeable $\mathrm{Hg}(0)$, particulate $\mathrm{Hg}$, and dissolved $\mathrm{Hg}$ (Figure S2). The purgeable $\mathrm{Hg}(0)$ was determined directly by purge-and-trap ICPMS. After purging, the sample solution in the bubbler was filtered with a $0.45 \mu \mathrm{m}$ membrane (PVDF) to differentiate dissolved and particulate $\mathrm{Hg}$.

The particulate $\mathrm{Hg}$, which is retained on the filter membrane (termed as $\mathrm{SPM}-\mathrm{Hg}$ ), was investigated for the $\mathrm{Hg}$ oxidation state by using a thermal desorption method based on the fact that $\mathrm{Hg}(0)$ and $\mathrm{Hg}(\mathrm{II})$ are released at different temperatures from the solid matrix. The thermal desorption method has been used before for $\mathrm{Hg}$ speciation in soils, which suggests that $\mathrm{Hg}(0)$ in the solid matrix could be released at $150-200{ }^{\circ} \mathrm{C}$, while $\mathrm{Hg}$ (II) requires higher temperature $\left(200-250{ }^{\circ} \mathrm{C}\right) .{ }^{46-48}$ Since ${ }^{201} \mathrm{Hg}(0)$ and ${ }^{199} \mathrm{Hg}(\mathrm{II})$ were spiked into the water, it is expected that ${ }^{201} \mathrm{Hg}$ would be released at a lower temperature, whereas ${ }^{199} \mathrm{Hg}$ at a higher one. The filter containing SPM-Hg was transferred into a glass tube $\left(1 / 4^{\prime \prime}\right.$ od $\left.\times 12 \mathrm{~cm}\right)$, with one end of tube being connected to Ar gas cylinder using Teflon tubing while the other to a soda lime drying column $\left(1 / 4^{\prime \prime}\right.$ od $\left.\times 10 \mathrm{~cm}\right)$ and then to a gold trap. The glass tube was heated at $150{ }^{\circ} \mathrm{C}$ for $40 \mathrm{~min}$ inside an oven to release particle-bound $\mathrm{Hg}(0)$ which was collected on the gold trap at an Ar flow of $350 \pm 35 \mathrm{~mL} \mathrm{~min}^{-1}$. After that a separate gold trap was connected to the glass tube which was then continued to be heated for another $40 \mathrm{~min}$ at $200{ }^{\circ} \mathrm{C}$ for release and collection of $\mathrm{Hg}(\mathrm{II})$. The gold traps were then connected to ICPMS and thermally desorbed at $500{ }^{\circ} \mathrm{C}$ with $\mathrm{Ar}$ $\left(200 \pm 20 \mathrm{~mL} \mathrm{~min}^{-1}\right)$ for $\mathrm{Hg}$ analysis.

For further fractionation of dissolved $\mathrm{Hg}$, the filtrate was reacted with acidic $\mathrm{SnCl}_{2}(20 \%, 0.2 \mathrm{~mL})$ solution $(\mathrm{pH}=2-3)$ and then purged with $\mathrm{Ar}$. The $\mathrm{Hg}$ collected and measured by this treatment, representing the fraction of $\operatorname{Hg}(0)$ that is weakly bound to dissolved substances (dissociated upon exposure to acidic solution) and/or the reactive $\mathrm{SnCl}_{2}$-reducable $\mathrm{Hg}^{2+}$ in the sample, was termed weakly bound $\mathrm{Hg}^{49,50}$ The filtrate after $\mathrm{SnCl}_{2}$ treatment was subjected to oxidation for $24 \mathrm{~h}$ after adding $2.0 \mathrm{~mL}$ of $\mathrm{BrCl}$ solution, followed by addition of $0.2 \mathrm{~mL}$ of $\mathrm{NH}_{2} \mathrm{OH} \cdot \mathrm{HCl}$ to consume excessive $\mathrm{BrCl}$. The $\mathrm{Hg}$ in the solution was then determined after adding $1.0 \mathrm{~mL}$ of $\mathrm{SnCl}_{2}$, followed by purge-and-trap-ICPMS. This fraction of $\mathrm{Hg}$, representing the $\mathrm{Hg}$ that was strongly bound with dissolved materials that was not directly reducible by $\mathrm{SnCl}_{2}$, was defined as strongly bound Hg. ${ }^{49,50}$

Determination of Dissolved and Particulate $\mathrm{Hg}(0)$ in Natural Waters. Since we observed in the experiments that formation of particulate $\mathrm{Hg}(0)$ through adsorption of $\mathrm{Hg}(0)$ on SPM was primarily accountable for the nonpurgeable $\mathrm{Hg}(0)$ and the interaction of spiked $\mathrm{Hg}(0)$ with ambient $\mathrm{Hg}$ could approximately reach equilibrium in $4 \mathrm{~h}$, we proposed a scheme for determination of both dissolved and particulate $\operatorname{Hg}(0)$ in natural waters using the purge-and-trap ID-ICPMS technique. Surface water samples were collected from the Florida Everglades, and each sample was split into two aliquots for $\mathrm{Hg}(0)$ analysis. First, one aliquot of water samples $(100 \mathrm{~mL})$ was spiked with ${ }^{201} \mathrm{Hg}(0)$ as ID $\mathrm{Hg}$ isotope upon arrival in the laboratory and immediately purged for $15 \mathrm{~min}$ at an Ar flow of $350 \pm 35 \mathrm{~mL} \mathrm{~min}^{-1}$ to collect $\mathrm{Hg}(0)$ onto a gold trap, followed by desorption and detection of the $\mathrm{Hg}$ collected on the trap using ID-ICPMS. This portion of $\mathrm{Hg}(0)$ represents the purgeable $\mathrm{Hg}(0)$ or DGM as commonly termed. Second, the other aliquot was spiked with ${ }^{201} \mathrm{Hg}(0)$ and left for $4 \mathrm{~h}$ for equilibration of the spiked ID isotope $\mathrm{Hg}$ with ambient $\mathrm{Hg}$ and then purged and 
determined for total $\mathrm{Hg}(0)$. The $\mathrm{Hg}(0)$ measured by this treatment is compensated for the interactions between $\mathrm{Hg}(0)$ and SPM in the natural water and can reasonably represent the total $\mathrm{Hg}(0)$ present in the water sample. Particulate $\mathrm{Hg}(0)$ was then calculated by the difference between total $\mathrm{Hg}(0)$ and DGM.

\section{RESULTS AND DISCUSSION}

Purgeability of $\mathrm{Hg}(0)$ in DI and Lake Waters. In initial experiments with DI water spiked with $\mathrm{Hg}(0)$, the recovery of $\mathrm{Hg}(0)$ was calculated by the purgeable $\mathrm{Hg}(0)$ divided by the sum of purgeable and nonpurgeable fractions of $\mathrm{Hg}(0)$. It was found that $\mathrm{Hg}(0)$ was fully recovered $(99.1 \pm 0.6 \%, n=3)$ when purge was carried out immediately $(0 \mathrm{~h})$ after $\mathrm{Hg}(0)$ being spiked into DI water, suggesting that the purge process was efficient and $\mathrm{Hg}(0)$ was not lost during the course of purging. Therefore, the $\mathrm{Hg}(0)$ purge recoveries in our other experiments were all calculated against the $\mathrm{Hg}(0)$ recovered at $0 \mathrm{~h}$ in $\mathrm{Hg}(0)$ spiked DI water. Recovery of the purgeable $\mathrm{Hg}(0)$ was further investigated after $\mathrm{Hg}(0)$ was spiked in DI water for $4 \mathrm{~h}$. A recovery of $91.8 \pm$ $11.2 \%(n=3)$ of $\mathrm{Hg}(0)$ indicates that $\mathrm{Hg}(0)$ can be still efficiently recovered through purging.

Different results were observed when similar experiments were performed with lake water (Figure 1). Recoveries of the
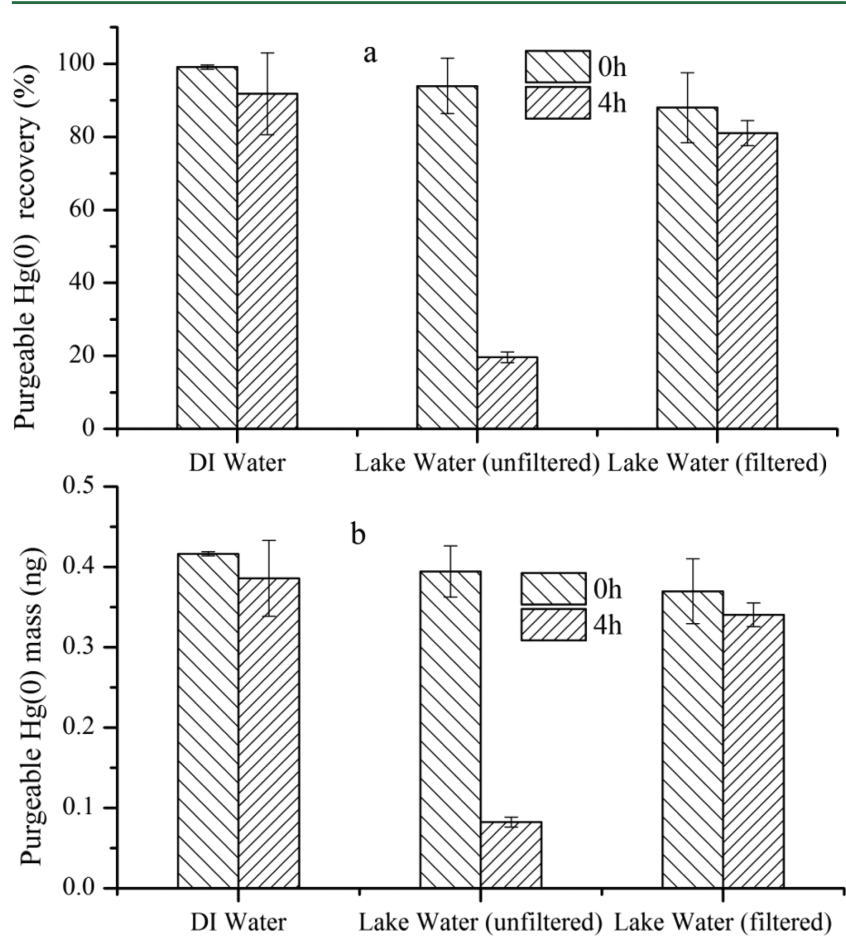

Figure 1. Purgeable $\mathrm{Hg}(0)$ a) recovery and b) mass after spiking $0.42 \mathrm{ng}$ of $\mathrm{Hg}(0)$ into $100 \mathrm{~mL}$ of deionized (DI) water, unfiltered natural water, and filtered (with $0.45 \mu \mathrm{m}$ PVDF membrane) natural water. Error bars are standard deviations $(n=3)$.

purgeable $\mathrm{Hg}(0)$ were $93.9 \pm 7.6 \%$ and $19.6 \pm 1.5 \%$ after $\mathrm{Hg}(0)$ was spiked into lake water for 0 and $4 \mathrm{~h}$, respectively, suggesting that a significant portion of $\mathrm{Hg}(0)$ was not purgeable in the water. One might speculate that a possible reason for the reduction in purge efficiency is that some $\operatorname{Hg}(0)$ may have converted to $\mathrm{Hg}$ (II) in lake water with time and hence cannot be purged out. However, these experiments were carried out in the dark, and thus photochemically induced $\mathrm{Hg}$ species transformation, i.e. oxidation of $\mathrm{Hg}(0)$ to $\mathrm{Hg}$ (II) or vice versa, can be eliminated. Our recent study on $\mathrm{Hg}$ redox reactions in Everglades water showed that dark oxidation of $\mathrm{Hg}(0)$ induced by microbial and chemical processes was insignificant, as evidenced by similarly slow oxidation rates of $\mathrm{Hg}(0)$ in sterilized and untreated water under dark conditions (unpublished data, see Figure S3). This observation is supported by a previous study where dark oxidation of $\mathrm{Hg}(0)$ in artificial and natural waters was not found to be statistically significant. ${ }^{16}$ Since photochemical reactions were eliminated in the experiments and microbial and chemical processes were not likely to oxidize a considerable amount of $\mathrm{Hg}(0)$ in the dark, we reasoned that the decrease in purge recovery of $\mathrm{Hg}(0)$ was plausibly due to the interaction of $\mathrm{Hg}(0)$ with particulate and/or dissolved substances (e.g., SPM and DOM) present in lake water, forming nonpurgeable SPM- and/ or DOM-bound $\operatorname{Hg}(0)$.

Effect of SPM and DOM in Natural Waters on $\mathrm{Hg}(0)$ Purgeability. The filtered lake water was spiked with ${ }^{201} \mathrm{Hg}(0)$ to assess the role of SPM on $\mathrm{Hg}(0)$ purgeability. The recoveries observed at 0 and $4 \mathrm{~h}$ after spiking were $88.0 \pm 9.6 \%$ and $81.0 \pm$ $3.5 \%$, respectively (Figure 1). Compared to these results, the purgeable $\mathrm{Hg}(0)$ in the unfiltered lake water (19.6 $\pm 1.5 \%$ recovered as aforementioned) significantly reduced after $4 \mathrm{~h}$ of equilibrium $(p<0.01, n=3)$. These results provided evidence that $\mathrm{Hg}(0)$ in natural water could bind with particulates, subsequently influencing $\mathrm{Hg}(0)$ purge recovery from water.

Since the $\operatorname{Hg}(0)$ spiked into the filtered lake water could be almost fully recovered through purging even after $4 \mathrm{~h}$ treatment, it is clear that potential interactions between $\mathrm{Hg}(0)$ and the dissolved substances, including DOM, played a minor role in affecting the purgeability of $\mathrm{Hg}(0)$. Separate experiments using commercially available DOM prepared at different concentrations indeed supported this notion, as seen in Figure 2 where the effects of the two types of HA on the recovery of purgeable $\mathrm{Hg}(0)$ were illustrated. Since the HA solutions were filtrated prior to use, the influence of particulates can be excluded. No significant decreases in purgeable $\mathrm{Hg}(0)$ were observed for the concentration ranges tested for both types of HA. However, it seemed that a larger portion of $\mathrm{Hg}(0)$ was retained by $\mathrm{HA} 2$ than

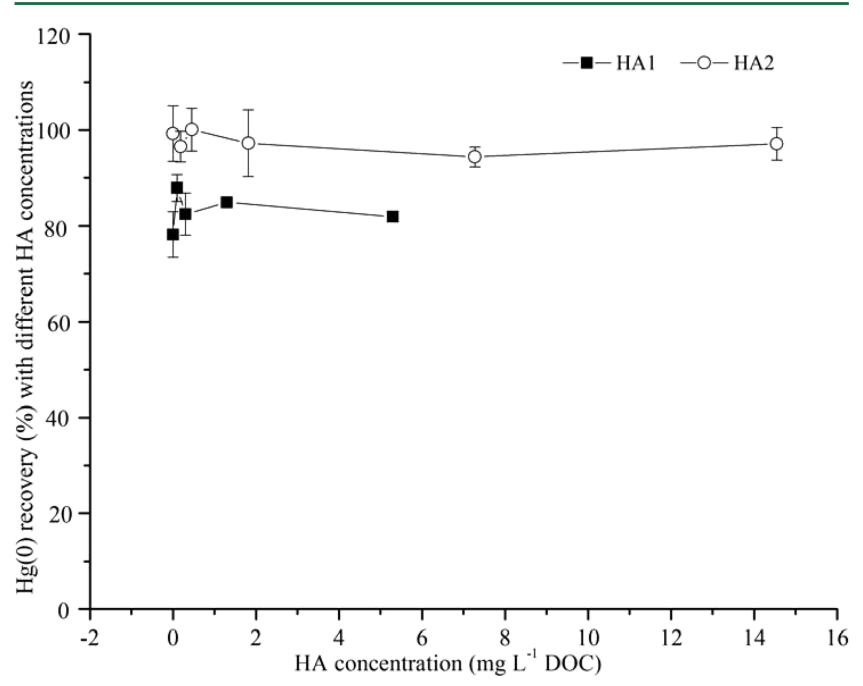

Figure 2. Recoveries of purgeable $\mathrm{Hg}(0)$ measured at $4 \mathrm{~h}$ after $0.42 \mathrm{ng}$ of $\mathrm{Hg}(0)$ being spiked in $100 \mathrm{~mL}$ of solutions with varying dissolved organic matter concentrations. Humic acids purchased from Acros (Sodium Salt, 50-60\% as HA) and from International Humic Substance Society (Waskish HA, peat, 1R107H) were used to prepare HA1 and HA2 solutions, respectively. 
by HA1, suggesting that characteristics of DOM could determine its role in affecting the purgeability of $\mathrm{Hg}(0)$. Although reduced DOM has been previously found to have a high affinity to $\mathrm{Hg}(0)$, this strong affinity was not observed for oxidized DOM, ${ }^{33}$ suggesting again that the differences in the DOM compositions and properties could affect the interactions between $\mathrm{Hg}(0)$ and DOM. Nevertheless, our results here indicate that DOM in natural water does not contribute significantly to the purge efficiency of $\mathrm{Hg}(0)$, in comparison to particulates.

Our experiments suggest the occurrence of SPM-bound $\mathrm{Hg}(0)$, presumably through adsorption of $\mathrm{Hg}(0)$ onto particles, which is nonpurgeable and in fact is the primary reason that causes low recoveries for the spiked $\operatorname{Hg}(0)$ when purging. It should be pointed out that particulate and dissolved phases are operationally defined terms as different sizes of filters have been used for fractionation, and here the $0.45 \mu \mathrm{m}$ cutoff was used to distinguish particulate- $\mathrm{Hg}$ from dissolved-Hg. It is possible that there are still colloidal particles below $0.45 \mu \mathrm{m}$. In this study we did not observe the effect of these colloidal particles on $\mathrm{Hg}(0)$ purging, probably because these smaller particles were not the major fraction of the SPM used here or some small sized particles could be purged out of solution. The situation might be different in some other cases where smaller particles constitute a considerable portion or SPM concentration is high (the SPM was $5.2 \mathrm{mg} \mathrm{L}^{-1}$ in this study). Very limited research has been done on the adsorption of $\mathrm{Hg}(0)$ on SPM in an aquatic environment, although adsorption of $\mathrm{Hg}(0)$ has been studied for such sorbents as activated carbon or noncarbon ${ }^{51-53}$ soil, ${ }^{3,46}$ and aquatic sediment. ${ }^{4}$ As particles are vital components of natural water and often the major carriers for metals, the adsorption of $\mathrm{Hg}$ on particles is a key factor determining the concentration of dissolved $\mathrm{Hg} .{ }^{4,34}$ Our results shown in this study call for a better understanding of the behavior of $\mathrm{Hg}(0)$ in aquatic environment, especially the interactions between $\mathrm{Hg}(0)$ and SPM.

Fractionation of Dissolved and Particulate $\mathrm{Hg}$ in Natural Water with $\mathrm{Hg}(0)$ Spiked. Knowing the concentration of total $\mathrm{Hg}(0)$, rather than the purgeable $\mathrm{Hg}(0)$ (or DGM) alone, in an aquatic environment is critical for a full understanding of the $\mathrm{Hg}$ biogeochemical cycle. Figure 3

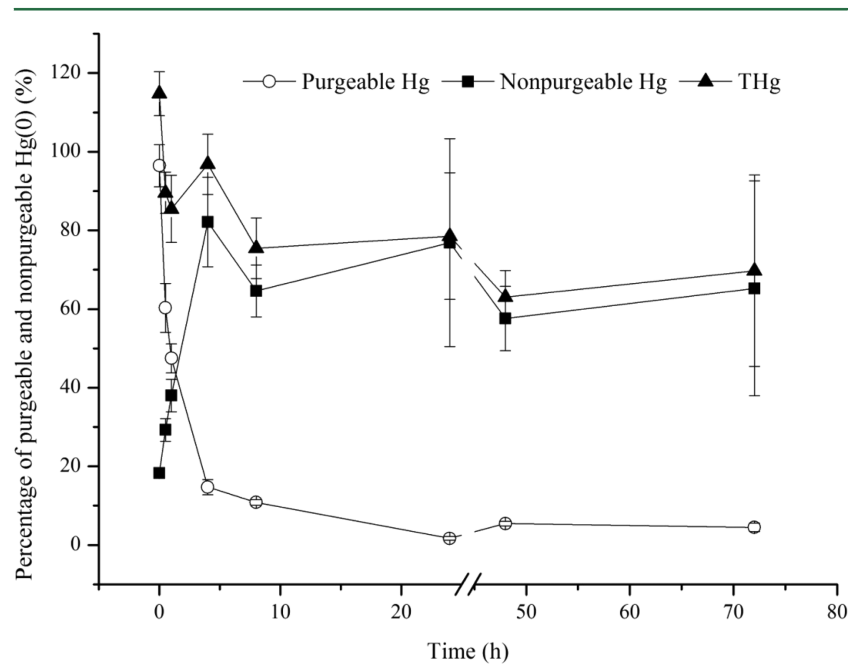

Figure 3. Changes of purgeable $\mathrm{Hg}(0)$, nonpurgeable $\mathrm{Hg}(0)$, and total $\mathrm{Hg}$ with time after $\mathrm{Hg}(0)$ being spiked into natural water. Natural water was spiked with $\mathrm{Hg}(0)$ at a final concentration of approximately $6.6 \mathrm{ng}$ $\mathrm{L}^{-1}$ and determined for purgeable and nonpurgeable $\mathrm{Hg}$ at different times. Error bars are standard deviations $(n=3)$. illustrates the variations in the distribution of purgeable and nonpurgeable $\mathrm{Hg}(0)$ in the experiments studying the kinetics of formation of SPM-bound $\mathrm{Hg}(0)$ after ${ }^{201} \mathrm{Hg}(0)$ was spiked into the lake water. Initially, the purgeable $\mathrm{Hg}(0)$ was $96.5 \pm 5.4 \%$ calculated against the amount of purgeable $\mathrm{Hg}(0)$ from DI water at $0 \mathrm{~h}$, indicating that instantaneous adsorption of $\mathrm{Hg}(0)$ to SPM was minimum. A rapid decrease in the purgeable $\mathrm{Hg}(0)$ with time was observed until $4 \mathrm{~h}$ when the trend of change reached a plateau with a purge recovery of $14.7 \pm 1.9 \%$. On the other hand, nonpurgeable $\mathrm{Hg}(0)$ was steadily increased and eventually reached a plateau of approximately $82.1 \pm 11.4 \%$ at $4 \mathrm{~h}$. Mass balance calculation indicates that about $20 \%$ of $\mathrm{Hg}(0)$ could be lost during the course of experiments, which is not unusual for experiments involving $\mathrm{Hg}(0)$ in an extended period of time.

Several processes could cause the conversion of the spiked ${ }^{201} \mathrm{Hg}(0)$ to nonpurgeable $\mathrm{Hg}$. Again, the oxidation of ${ }^{201} \mathrm{Hg}(0)$ to ${ }^{201} \mathrm{Hg}$ (II) could not be accountable for the loss of purgeable $\mathrm{Hg}(0)$, as all experiments were performed in the dark. Therefore, it seems reasonable to presume that the decrease in the purgeable $\mathrm{Hg}(0)$ with time could be the results of adsorption of $\mathrm{Hg}(0)$ onto SPM forming nonpurgeable particulate $\mathrm{Hg}(0)$ in natural water. Indeed, the fractionation of dissolved and particulate $\mathrm{Hg}$ using lake water spiked with both ${ }^{201} \mathrm{Hg}(0)$ and ${ }^{199} \mathrm{Hg}(\mathrm{II})$, where directly purgeable $\mathrm{Hg}(0), \mathrm{SPM}-\mathrm{Hg}$, and dissolved $\mathrm{Hg}$ were determined, supports this presumption. After $4 \mathrm{~h}$ equilibrium, only $18.8 \pm 3.3 \%$ of ${ }^{201} \mathrm{Hg}(0)$ was directly purged out, confirming that the majority of ${ }^{201} \mathrm{Hg}(0)$ was nonpurgeable and associated with SPM and/or dissolved substances with the former and the latter being about 70 and $20 \%$ of $\mathrm{Hg}(0)$ spiked, respectively, as revealed by further speciation analysis after filtration (Table 1 ). The dissolved $\mathrm{Hg}$ in the filtrate was further fractionationed into weakly and strongly bound $\mathrm{Hg}$ fractions (see Experiments section for their operational definitions), with the former accounting for $6.1 \pm 0.76 \%$ of spiked ${ }^{201} \mathrm{Hg}$ and the latter 14.7 $\pm 3.0 \%$.

For the particulate fraction of ${ }^{201} \mathrm{Hg}(0)$, which accounts for $68.2 \pm 8.1 \%$ of the spiked ${ }^{201} \mathrm{Hg}(0), 33.2 \pm 3.3 \%$ and $35.0 \pm 6.3 \%$ (calculated against the amount of ${ }^{201} \mathrm{Hg}$ spiked) were desorbed upon thermal desorption at 150 and $200{ }^{\circ} \mathrm{C}$ (Table 1), suggesting that the ${ }^{201} \mathrm{Hg}$ adsorbed on SPM should be primarily in the form of $\mathrm{Hg}(0)$. On the contrary, for SPM-bound ${ }^{199} \mathrm{Hg}(\mathrm{II})$, only less than $10 \%$ of the spiked ${ }^{199} \mathrm{Hg}$ was released at $150{ }^{\circ} \mathrm{C}$ and about $25 \%$ at $200{ }^{\circ} \mathrm{C}$. Considering that thermal desorption at 150 ${ }^{\circ} \mathrm{C}$ would exclusively release $\mathrm{Hg}(0)$, and at $200{ }^{\circ} \mathrm{C} \mathrm{Hg}(0)$ would still be the primary form of $\mathrm{Hg}$ released plus a small portion of other $\mathrm{Hg}$ species based on previous thermal desorption studies, ${ }^{4,46,48}$ it is conceivable that the majority of the spiked ${ }^{201} \mathrm{Hg}(0)$ became nonpurgeable due to the formation of SPM$\mathrm{Hg}(0)$ through $\mathrm{Hg}(0)$ adsorption on SPM. Quantitative recovery of ${ }^{201} \mathrm{Hg}(0)$ spiked $(107.3 \pm 4.6 \%)$ lends further support on the SPM-bound ${ }^{201} \mathrm{Hg}$ being $\mathrm{Hg}(0)$ and also validates the procedures used here to evaluate the speciation and distribution of $\mathrm{Hg}(0)$ in natural water. For ${ }^{199} \mathrm{Hg}(\mathrm{II})$-spiked trials, total recovery was found to be $83.6 \pm 2.3 \%$, indicating approximately $15-20 \%$ of the spiked $\mathrm{Hg}$ (II) were not recovered by this speciation protocol. This is probably because a fraction of $\mathrm{Hg}$ (II) associated with SPM could not be released from SPM after the thermal treatment used here (up to $200{ }^{\circ} \mathrm{C}$ ), as the complete release of $\mathrm{Hg}$ (II) from solids requires higher temperatures (e.g., $\left.220-250{ }^{\circ} \mathrm{C}\right) .{ }^{46,48}$ It should be noted that thermal desorption is not a precise method for $\mathrm{Hg}$ speciation analysis, as release of each $\mathrm{Hg}$ species occurs within a temperature range and is dependent upon a solid matrix. For 
Table 1. Percentage (\%) Distribution of Different $\mathrm{Hg}$ Species after Spiking ${ }^{201} \mathrm{Hg}(0)$ and ${ }^{199} \mathrm{Hg}(\mathrm{II})(0.783$ and $1.356 \mathrm{ng}$, Respectively) into Natural Water for $4 \mathrm{~h}$

\begin{tabular}{|c|c|c|c|c|c|c|c|}
\hline & \multirow[b]{2}{*}{ purgeable $\mathrm{Hg}$} & \multicolumn{3}{|c|}{ SPM-Hg } & \multirow[b]{2}{*}{ weekly bound $\mathrm{Hg}$} & \multirow[b]{2}{*}{ strongly bound $\mathrm{Hg}$} & \multirow[b]{2}{*}{ total $\mathrm{Hg}$} \\
\hline & & $150^{\circ}$ & $200^{\circ}$ & total & & & \\
\hline${ }^{201} \mathrm{Hg}(0)$ & $18.8 \pm 3.3$ & $33.2 \pm 3.3$ & $35.0 \pm 6.3$ & $68.2 \pm 8.1$ & $6.1 \pm 0.8$ & $14.7 \pm 3.0$ & $107.3 \pm 4.6$ \\
\hline${ }^{199} \mathrm{Hg}(\mathrm{II})$ & $3.3 \pm 0.3$ & $10.0 \pm 3.2$ & $25.2 \pm 4.2$ & $35.2 \pm 7.0$ & $32.4 \pm 4.76$ & $12.7 \pm 2.15$ & $83.6 \pm 2.3$ \\
\hline
\end{tabular}

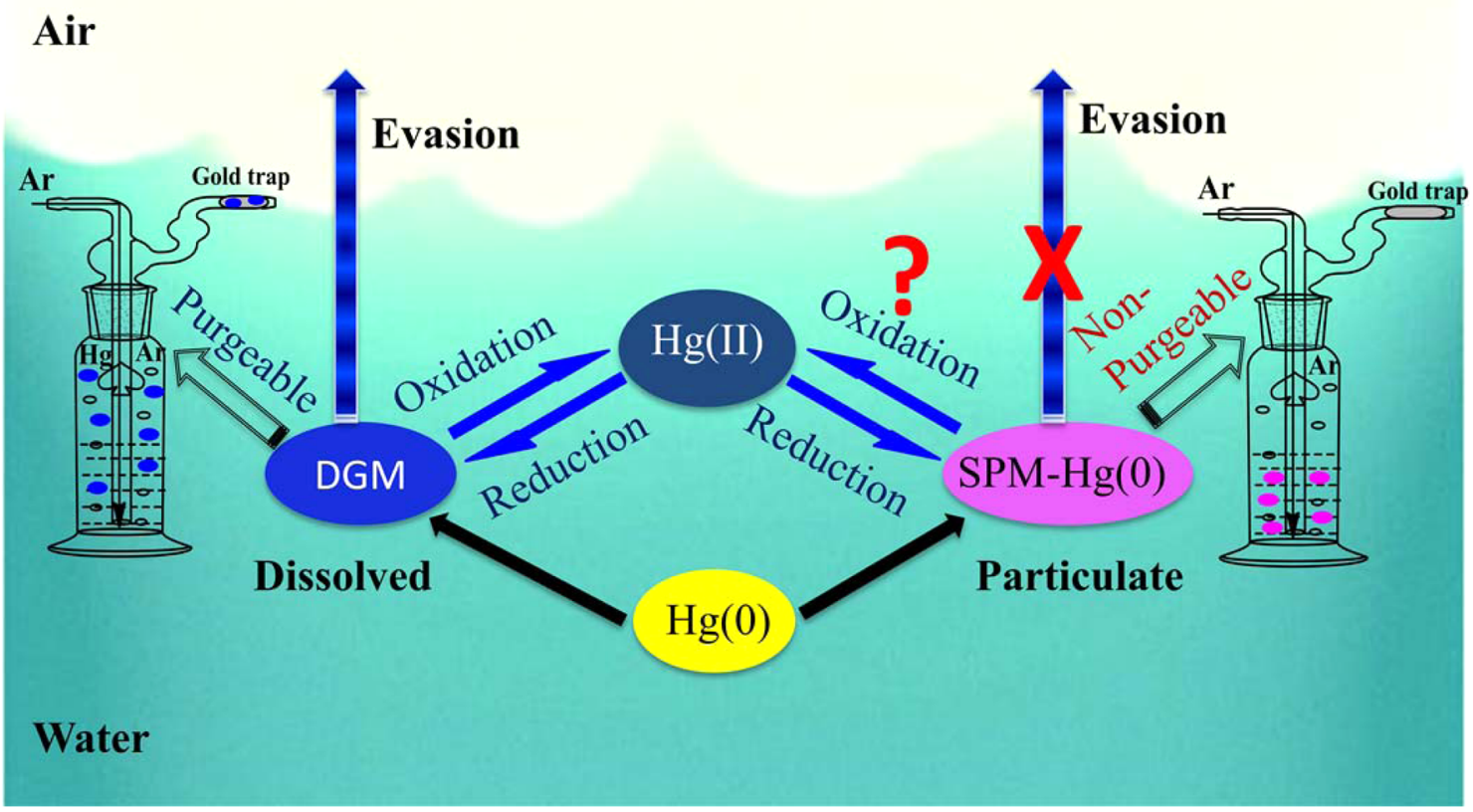

Figure 4. A diagram depicting the presence and different behavior of dissolved and particulate $\mathrm{Hg}(0)$ in aquatic environments.

example, it was observed that, when heating airborne particles, a minor amount of $\mathrm{HgCl}_{2}$ could be released even at $150{ }^{\circ} \mathrm{C} .{ }^{54}$ That is why we used a study design of simultaneously spiking isotopic ${ }^{201} \mathrm{Hg}(0)$ and ${ }^{199} \mathrm{Hg}(\mathrm{II})$, where different behavior of SPM-bound $\mathrm{Hg}(0)$ and $\mathrm{Hg}$ (II) upon thermal desorption could be compared.

Determination of Dissolved and Particulate $\mathrm{Hg}(0)$ in Natural Waters. It can be seen from this study that determination of total $\mathrm{Hg}(0)$ in natural waters cannot be performed by direct purge with $\mathrm{Ar}$, as currently employed in the conventional $\mathrm{Hg}(0)$ determination method, due to the presence of nonpurgeable particulate $\mathrm{Hg}(0)$. Even the employment of ID, which can overcome the potential $\mathrm{Hg}(0)$ loss during the sample treatment by being corrected by an equivalent loss of the ID $\mathrm{Hg}$ isotope, ${ }^{44}$ would significantly underestimate the concentration of total $\mathrm{Hg}(0)$ if purged immediately after spiking ID isotope. This is because the $\operatorname{Hg}(0)$ spiked into water will interact with SPM and substitute endogenous $\operatorname{Hg}(0)$, and the interaction of the spiked and ambient $\mathrm{Hg}$ will take time to reach equilibrium.

The proposed scheme for determination of particulate $\mathrm{Hg}(0)$ was applied to Everglades water, and samples were collected and analyzed for both DGM and total $\mathrm{Hg}(0)$. The Everglades water has a $\mathrm{pH}$ of 7.2-7.8, DOC of 5.7-24.1 $\mathrm{mg} \mathrm{L}^{-1}$, and SPM of 1.7$3.1 \mathrm{mg} \mathrm{L}{ }^{-1}$. Before the application, it was estimated that the method detection limit (MDL), determined as three times standard deviation of seven replicate measurements of a blank solution, was $0.1 \mathrm{ng} \mathrm{L}^{-1}$ for $\mathrm{Hg}(0)$. The precision of the method, calculated as relative standard deviation of triplicate measurements of one sample, was approximately 5-15\%. The determined DGM in Everglades water ranged from 0.14 to $0.22 \mathrm{ng} \mathrm{L}^{-1}$, whereas total $\mathrm{Hg}(0)$ ranged from 0.41 to $0.75 \mathrm{ng}$
$\mathrm{L}^{-1}$. The discrepancies between DGM and total $\mathrm{Hg}(0)$ indicate that nonpurgeable particulate $\mathrm{Hg}(0)$ is indeed present in Everglades water, and the fraction of particulate $\mathrm{Hg}(0)$ against total $\mathrm{Hg}(0)$ could vary from approximately $45-80 \%$. It should be pointed out that the equilibrium time required after ID $\mathrm{Hg}(0)$ isotope being spiked may vary with the type of natural waters $(4 \mathrm{~h}$ for this study), and the appropriate equilibration time should be determined prior to analysis for other water samples.

It is clearly demonstrated in our study the occurrence of particulate ${ }^{201} \mathrm{Hg}(0)$ through $\mathrm{Hg}(0)$ adsorption on SPM, which could account for the majority of $\mathrm{Hg}(0)$ spiked, after ${ }^{201} \mathrm{Hg}(0)$ was added into water samples. As the dissolved and particulate $\mathrm{Hg}(0)$ should be in a dynamic equilibrium, one can comfortably reason that the ambient $\mathrm{Hg}(0)$ originally present in the water samples should include both dissolved and SPM-bound forms. Since $\mathrm{Hg}(0)$ has a high affinity to be adsorbed on SPM as shown here, it seems reasonable to presume that particulate $\mathrm{Hg}(0)$ would be widely present in natural waters due to the ubiquity of SPM. The test results of Everglades water confirmed the presence of particulate $\mathrm{Hg}(0)$ in natural waters and as a major fraction of $\mathrm{Hg}(0)$. Therefore, particulate $\mathrm{Hg}(0)$ must be considered, in addition to DGM, to fully understand aquatic $\mathrm{Hg}$ cycling, as these two species have distinct characteristics. Figure 4 depicted the presence and different behavior of dissolved and particulate $\mathrm{Hg}(0)$ in aquatic environments, which sheds some light on exploring environmental implications of particulate $\mathrm{Hg}(0)$. First, particulate $\mathrm{Hg}(0)$ is nonpurgeable and thus could be easily omitted if the conventional direct purge and trap method is used to measure $\operatorname{Hg}(0)$ in water. The omission of particulate $\mathrm{Hg}(0)$ in this type of measurement may 
affect the interpretation of results in $\mathrm{Hg}$ redox reaction studies. In a previous study on ocean water dynamics of $\mathrm{Hg}(0)$, Qureshi et al. observed different rate constants using instantaneous photoreduction and purging method, and they suggest this is due to $\mathrm{Hg}(0)$ binding to particles, ${ }^{55}$ which is probably the case given our results presented here. Second, due to its nonpurgeability, particulate $\mathrm{Hg}(0)$ is not expected to evade into the atmosphere, as opposed to DGM. However, little is known about the stability of particulate $\mathrm{Hg}(0)$ through time and how it will affect $\mathrm{Hg}(0)$ release and volatilization. For field studies purging samples to determine $\mathrm{Hg}(0)$ will particulate $\mathrm{Hg}(0)$ change during sample transport and storage and thus affect the measurement, if purging is not done immediately on site. Last, although dissolved $\operatorname{Hg}(0)$ could be (photochemically and microbially) oxidized to $\mathrm{Hg}$ (II) in water, little is known about the chemical, photochemical, and microbial reactivity of particulate $\operatorname{Hg}(0)$. Diurnal dynamics of DGM have been observed in natural waters, but how much of the patterns observed are due to $\mathrm{Hg}(0)$ binding to particulates rather than reoxidation. Further studies are warranted to examine the role of particulate $\mathrm{Hg}(0)$ in $\mathrm{Hg}$ oxidation/reduction, air-water $\mathrm{Hg}$ transport, and the global biogeochemical cycling of $\mathrm{Hg}$.

\section{ASSOCIATED CONTENT}

\section{S Supporting Information}

The Supporting Information is available free of charge on the ACS Publications website at DOI: 10.1021/acs.est.5b01940.

Detailed information on instrumentation, materials, and experimental procedures; discussion on the effect of HAs on $\mathrm{Hg}(0)$ purgeability; a figure showing microbial and chemical oxidation of $\mathrm{Hg}(0)$ in the dark insignificant; and a figure showing $\mathrm{Hg}(0)$ adsorption on magnetite particles (PDF)

\section{AUTHOR INFORMATION}

\section{Corresponding Authors}

*Phone: 86-013983206870. E-mail: dywang@swu.edu.cn (D.W.).

*Phone: 1-305-348-6210. E-mail: cai@fiu.edu (Y.C.).

\section{Notes}

The authors declare no competing financial interest.

\section{ACKNOWLEDGMENTS}

This research was sponsored by the National Basic Research Program of China (2013CB430002 and 2013CB430004), National Natural Science Foundation of China (21120102040, 20937002), and the U.S. Department of Energy (DE-FG0105EW07033). This is contribution No. 737 of Southeast Environmental Research Center at FIU.

\section{REFERENCES}

(1) Liu, G.; Cai, Y.; O’Driscoll, N. Environmental Chemistry and Toxicology of Mercury; John Wiley \& Sons, Inc.: New Jersey, US, 2012; pp 1-574.

(2) Graydon, J. A.; St. Louis, V. L.; Hintelmann, H.; Lindberg, S. E.; Sandilands, K. A.; Rudd, J. W.; Kelly, C. A.; Hall, B. D.; Mowat, L. D. Long-term wet and dry deposition of total and methyl mercury in the remote boreal ecoregion of Canada. Environ. Sci. Technol. 2008, 42, 8345-8351.

(3) Fang, S. C. Studies on the sorption of elemental mercury vapor by soils. Arch. Environ. Contam. Toxicol. 1981, 10, 193-201.

(4) Bouffard, A.; Amyot, M. Importance of elemental mercury in lake sediments. Chemosphere 2009, 74, 1098-1103.
(5) Baeyens, W.; Leermakers, M. Elemental mercury concentrations and formation rates in the Scheldt estuary and the North Sea. Mar. Chem. 1998, 60, 257-266.

(6) Amyot, M.; Gill, G. A.; Morel, F. M. Production and loss of dissolved gaseous mercury in coastal seawater. Environ. Sci. Technol. 1997, 31, 3606-3611.

(7) Siciliano, S. D.; O’Driscoll, N. J.; Lean, D. Microbial reduction and oxidation of mercury in freshwater lakes. Environ. Sci. Technol. 2002, 36, 3064-3068.

(8) Amyot, M.; Morel, F. M.; Ariya, P. A. Dark oxidation of dissolved and liquid elemental mercury in aquatic environments. Environ. Sci. Technol. 2005, 39, 110-114.

(9) Amyot, M.; Lean, D. R.; Poissant, L.; Doyon, M.-R. Distribution and transformation of elemental mercury in the St. Lawrence River and Lake Ontario. Can. J. Fish. Aquat. Sci. 2000, 57, 155-163.

(10) Murphy, E. A.; Dooley, J.; Windom, H. L.; Smith, R. G., Jr Mercury species in potable ground water in southern New Jersey. Water, Air, Soil Pollut. 1994, 78, 61-72.

(11) Walvoord, M. A.; Andraski, B. J.; Krabbenhoft, D. P.; Striegl, R. G. Transport of elemental mercury in the unsaturated zone from a waste disposal site in an arid region. Appl. Geochem. 2008, 23, 572-583.

(12) Mason, R. P. Mercury emissions from natural processes and their importance in the global mercury cycle. In Mercury fate and transport in the global atmosphere; Springer: 2009; pp 173-191.

(13) Hu, H.; Lin, H.; Zheng, W.; Tomanicek, S. J.; Johs, A.; Feng, X.; Elias, D. A.; Liang, L.; Gu, B. Oxidation and methylation of dissolved elemental mercury by anaerobic bacteria. Nat. Geosci. 2013, 6, 751-754.

(14) Colombo, M. J.; Ha, J.; Reinfelder, J. R.; Barkay, T.; Yee, N. Anaerobic Oxidation of $\mathrm{Hg}(0)$ and Methylmercury Formation by Desulfovibrio desulfuricans ND132. Geochim. Cosmochim. Acta 2013, 112, 166-177.

(15) Whalin, L.; Kim, E.-H.; Mason, R. Factors influencing the oxidation, reduction, methylation and demethylation of mercury species in coastal waters. Mar. Chem. 2007, 107, 278-294.

(16) Lalonde, J. D.; Amyot, M.; Kraepiel, A. M.; Morel, F. M. Photooxidation of $\mathrm{Hg}(0)$ in artificial and natural waters. Environ. Sci. Technol. 2001, 35, 1367-1372.

(17) Lalonde, J. D.; Amyot, M.; Orvoine, J.; Morel, F. M.; Auclair, J.-C.; Ariya, P. A. Photoinduced oxidation of $\mathrm{HgO}(\mathrm{aq})$ in the waters from the St. Lawrence estuary. Environ. Sci. Technol. 2004, 38, 508-514.

(18) Zhang, H.; Lindberg, S. E. Sunlight and iron (III)-induced photochemical production of dissolved gaseous mercury in freshwater. Environ. Sci. Technol. 2001, 35, 928-935.

(19) O'Driscoll, N. J.; Siciliano, S.; Lean, D.; Amyot, M. Gross photoreduction kinetics of mercury in temperate freshwater lakes and rivers: Application to a general model of DGM dynamics. Environ. Sci. Technol. 2006, 40, 837-843.

(20) O’Driscoll, N. J.; Lean, D.; Loseto, L.; Carignan, R.; Siciliano, S. Effect of dissolved organic carbon on the photoproduction of dissolved gaseous mercury in lakes: Potential impacts of forestry. Environ. Sci. Technol. 2004, 38, 2664-2672.

(21) Poulain, A.; Amyot, M.; Findlay, D.; Telor, S.; Barkay, T.; Hintelmann, H. Biological and photochemical production of dissolved gaseous mercury in a boreal lake. Limnol. Oceanogr. 2004, 49, 22652275.

(22) Poulain, A. J.; Garcia, E.; Amyot, M.; Campbell, P. G.; Raofie, F.; Ariya, P. A. Biological and chemical redox transformations of mercury in fresh and salt waters of the High Arctic during spring and summer. Environ. Sci. Technol. 2007, 41, 1883-1888.

(23) Barkay, T.; Miller, S. M.; Summers, A. O. Bacterial mercury resistance from atoms to ecosystems. FEMS Microbiol. Rev. 2003, 27, $355-384$.

(24) Garcia, E.; Amyot, M.; Ariya, P. A. Relationship between DOC photochemistry and mercury redox transformations in temperate lakes and wetlands. Geochim. Cosmochim. Acta 2005, 69, 1917-1924.

(25) Wiatrowski, H. A.; Das, S.; Kukkadapu, R.; Ilton, E. S.; Barkay, T.; Yee, N. Reduction of $\mathrm{Hg}$ (II) to $\mathrm{Hg}(0)$ by magnetite. Environ. Sci. Technol. 2009, 43, 5307-5313. 
(26) Ravichandran, M. Interactions between mercury and dissolved organic matter--a review. Chemosphere 2004, 55, 319-331.

(27) Zheng, W.; Liang, L.; Gu, B. Mercury reduction and oxidation by reduced natural organic matter in anoxic environments. Environ. Sci. Technol. 2012, 46, 292-299.

(28) Seller, P.; Kelly, C.; Rudd, J.; MacHutchon, A. Photodegradation of methylmercury in lakes. Nature 1996, 380, 694-697.

(29) Hammerschmidt, C. R.; Fitzgerald, W. F. Photodecomposition of methylmercury in an arctic Alaskan lake. Environ. Sci. Technol. 2006, 40, $1212-1216$.

(30) Li, Y.; Cai, Y. Progress in the study of mercury methylation and demethylation in aquatic environments. Chin. Sci. Bull. 2013, 58, 177185.

(31) Landa, E. R. The retention of metallic mercury vapor by soils. Geochim. Cosmochim. Acta 1978, 42, 1407-1411.

(32) Fang, S. C. Sorption and transformation of mercury vapor by dry soil. Environ. Sci. Technol. 1978, 12, 285-288.

(33) Gu, B.; Bian, Y.; Miller, C. L.; Dong, W.; Jiang, X.; Liang, L. Mercury reduction and complexation by natural organic matter in anoxic environments. Proc. Natl. Acad. Sci. U. S. A. 2011, 108, 14791483.

(34) Tseng, C.; Lamborg, C.; Fitzgerald, W.; Engstrom, D. Cycling of dissolved elemental mercury in Arctic Alaskan lakes. Geochim. Cosmochim. Acta 2004, 68, 1173-1184.

(35) Monperrus, M.; Tessier, E.; Amouroux, D.; Leynaert, A.; Huonnic, P.; Donard, O. Mercury methylation, demethylation and reduction rates in coastal and marine surface waters of the Mediterranean Sea. Mar. Chem. 2007, 107, 49-63.

(36) Heyes, A.; Mason, R. P.; Kim, E.-H.; Sunderland, E. Mercury methylation in estuaries: Insights from using measuring rates using stable mercury isotopes. Mar. Chem. 2006, 102, 134-147.

(37) Hintelmann, H.; Evans, R. D.; Villeneuve, J. Y. Measurement of mercury methylation in sediments by using enriched stable mercury isotopes combined with methylmercury determination by gas chromatography-inductively coupled plasma mass spectrometry. $J$. Anal. At. Spectrom. 1995, 10, 619-624.

(38) Hintelmann, H.; Keppel -Jones, K.; Evans, R. D. Constants of mercury methylation and demethylation rates in sediments and comparison of tracer and ambient mercury availability. Environ. Toxicol. Chem. 2000, 19, 2204-2211.

(39) Li, Y.; Mao, Y.; Liu, G.; Tachiev, G.; Roelant, D.; Feng, X.; Cai, Y. Degradation of methylmercury and its effects on mercury distribution and cycling in the Florida Everglades. Environ. Sci. Technol. 2010, 44, 6661-6666.

(40) Bridou, R.; Monperrus, M.; Gonzalez, P. R.; Guyoneaud, R.; Amouroux, D. Simultaneous determination of mercury methylation and demethylation capacities of various sulfate-reducing bacteria using species-specific isotopic tracers. Environ. Toxicol. Chem. 2011, 30, 337344.

(41) Rodríguez Martín-Doimeadios, R. C.; Tessier, E.; Amouroux, D.; Guyoneaud, R.; Duran, R.; Caumette, P.; Donard, O. Mercury methylation/demethylation and volatilization pathways in estuarine sediment slurries using species-specific enriched stable isotopes. Mar. Chem. 2004, 90, 107-123.

(42) Rodríguez-González, P.; Marchante-Gayón, J. M.; García Alonso, J. I.; Sanz-Medel, A. Isotope dilution analysis for elemental speciation: a tutorial review. Spectrochim. Acta, Part B 2005, 60, 151-207.

(43) Rodríguez Martin-Doimeadios, R.; Krupp, E.; Amouroux, D.; Donard, O. Application of isotopically labeled methylmercury for isotope dilution analysis of biological samples using gas chromatography/ICPMS. Anal. Chem. 2002, 74, 2505-2512.

(44) Jackson, B.; Taylor, V.; Baker, R. A.; Miller, E. Low-level mercury speciation in freshwaters by isotope dilution GC-ICP-MS. Environ. Sci. Technol. 2009, 43, 2463-2469.

(45) Miller, C. L.; Southworth, G.; Brooks, S.; Liang, L.; Gu, B. Kinetic controls on the complexation between mercury and dissolved organic matter in a contaminated environment. Environ. Sci. Technol. 2009, 43, $8548-8553$.
(46) Windmöller, C. C.; Wilken, R.-D.; Jardim, W. D. F. Mercury speciation in contaminated soils by thermal release analysis. Water, Air, Soil Pollut. 1996, 89, 399-416.

(47) Liu, G.; Cabrera, J.; Allen, M.; Cai, Y. Mercury characterization in a soil sample collected nearby the DOE Oak Ridge Reservation utilizing sequential extraction and thermal desorption method. Sci. Total Environ. 2006, 369, 384-392.

(48) Bombach, G.; Bombach, K.; Klemm, W. Speciation of mercury in soils and sediments by thermal evaporation and cold vapor atomic absorption. Fresenius' J. Anal. Chem. 1994, 350, 18-20.

(49) USEPA. Method 1631: Revision E, Mercury in water by Oxidation, Purge and Trap, and Cold Vapor atomic Fluorescence Spectrometry; United States Environmental Protection Agency: 2002; pp 1-33.

(50) Paraquetti, H. H. M.; Lacerda, L. D.; Ayres, G. A.; Mounier, S.; Almeida, M. D. Mercury speciation and dissolved organic carbon characterization in the surface waters of Sepetiba bay, Se Brazil. Geochim. Brasil 2004, 18, 028-037.

(51) Lee, J.-Y.; Ju, Y.; Keener, T. C.; Varma, R. S. Development of costeffective noncarbon sorbents for $\mathrm{Hg} 0$ removal from coal-fired power plants. Environ. Sci. Technol. 2006, 40, 2714-2720.

(52) Yang, H.; Xu, Z.; Fan, M.; Bland, A. E.; Judkins, R. R. Adsorbents for capturing mercury in coal-fired boiler flue gas. J. Hazard. Mater. 2007, 146, 1-11.

(53) Serre, S. D.; Silcox, G. D. Adsorption of elemental mercury on the residual carbon in coal fly ash. Ind. Eng. Chem. Res. 2000, 39, 1723-1730.

(54) Feng, X.; Lu, J.; Grègoire, D. C.; Hao, Y.; Banic, C.; Schroeder, W. Analysis of inorganic mercury species associated with airborne particulate matter/aerosols: method development. Anal. Bioanal. Chem. 2004, 380, 683-689.

(55) Qureshi, A.; O'Driscoll, N. J.; MacLeod, M.; Neuhold, Y.-M.; Hungerbühler, K. Photoreactions of Mercury in Surface Ocean Water: Gross Reaction Kinetics and Possible Pathways. Environ. Sci. Technol. 2010, 44, 644-649. 